\title{
The consumer intention to use digital membership cards
}

\author{
Fergyanto E. Gunawan \\ Inka Sari \\ Yanfi
}

Bina Nusantara University, Jakarta, Indonesia

\section{Keywords}

Loyalty Program, User Acceptance, Mobile Apps, Customer Relationship Management

\begin{abstract}
The study focuses on the consumer perception regarding digital membership card, an trendy instrument in the customer relationship management (CRM). It adopts the Unified Theory of Acceptance of the Use of Technology 2, which takes into account the following determinants: performance expectancy, effort expectancy, social influence, facilitating conditions, hedonic motivation, price value, and habit. The population of the study is consumers having any membership cards. The data are collected from a random sample by using questionnaires on the Likert scale. The collected empirical data in conjunction with a multivariate regression model suggest the followings. The price value aspect is the key factor influencing the continuous intention of use of the instrument. The aspects of social influence, performance expectation, and effort expectation are more important than the hedonic motivation aspect. The findings imply that for companies to succeed with the digital CRM instrument, offering strong competitive advantages at a lower price is still important as much as the user friendliness of the device.
\end{abstract}

Corresponding author: Fergyanto E. Gunawan

Email addresses for the corresponding author: fgunawan@binus.edu

First submission received: $29^{\text {th }}$ January 2018

Revised submission received: $12^{\text {th }}$ April 2018

Accepted: $12^{\text {th }}$ November 2018

\section{Introduction}

Smartphone is a pervasive device of mobile information and communication technology (ICT). As February 2015, the number of smartphone users has reached $68 \%$ of the global population, accounted for 1.2 billion smartphones (BuzzCity Report, 2015). Credit Suisse predicted that the smartphone ownership would approach $90 \%$ of the population or about 4.95 billion people (Booton, 2015). Without any doubt, the proliferation of the smartphone affects many aspects of business strategies including customer relationship management (CRM).

CRM is a marketing practice with the intention to maximize the lifetime of customers on firms. CRM often uses ICT to leverage its practices (Reinartz, 2004). For example, the present company may use Google Cloud Messaging (GCM) to spread information and promote products of new programs at a low cost (Yilmaz,Y.S., Aydin,B.,I., and Demirbas, M., 2014).

Due to the widespread of smartphones, the use of digital membership program in the form of mobile applications is gaining traction (Fujiwara \& Nagasawa, 2015). We also witness the fact that the number of mobile applications has been growing exponentially but many of them are abandoned by their users. Application abandonment is mainly fueled by the loss of interest. For the reason, many studies have been performed to explore and investigate the usage of mobile apps including the use of transformational and informational mobile apps strategies to motivate usage (Kim et al., 2013; Campbell and Kwak, 2010; LaRue et al., 2010; Vladar and Fife, 2010; Wang and Wang, 2010). The use of mobile apps for branding was discussed in a great detail in Bellman et al., (2011). The relationship between experiential values and the use of mobile apps was studied by Maghnati and Ling (2013). However, how the users accept mobile apps for the purpose of customer loyalty membership programs is still unclear. This issue is the main research topic of this article. 


\section{Research Method}

To understand the factors affecting the adoption and use of the digital membership apps, we use the Unified Theory of Acceptance and Use of Technology (UTAUT). According to Venkatesh et al. (2003), UTAUT is preceded by eight theories, namely, Theory of Reasoned Action (TRA), Technology Acceptance Model/Technology Acceptance Model 2 (TAM/TAM2), Theory of Planned Behavior/Decomposed Theory of Planned Behavior (TPB/DTPB), Social Cognitive Theory (SCT), Innovation Diffusion Theory (IDT), Motivation Model (MM), Combined-TAM-TPB and Model of PC Utilization (MPCU). Table 1 presents the relevant articles for those theories and their variables.

The current research framework is depicted in Figure 1. The focus of the research is on the behavioral intention of the users of a digital membership instrument in the form of an app. Furthermore, the research seeks to understand how the intention is affected by the performance expectancy, effort expectancy, social influence, facilitating conditions, hedonic motivation, price value, and habit.

The required data are collected by questionnaires from a sample of 345 active users of the app. The instrument consists of questions in Likert scale where 1 is associated with strongly disagree and 5 is strongly agree. The obtained responses are used to establish a linear multivariate model of:

$$
Y=\beta_{0}+\beta_{1} X_{1}+\beta_{2} X_{2}+\beta_{3} X_{3}+\beta_{4} X_{4}+\beta_{5} X_{5}+\beta_{6} X_{6}+\beta_{7} X_{7}
$$

where the variable $Y$ denotes the behavioral intention, $X_{1}$ is the performance expectancy, $X_{2}$ is the effort expectancy, $X_{3}$ is the social influence, $X_{4}$ is the facilitating condition, $X_{5}$ is the hedonic motivation, $X_{6}$ is the price value, and finally, $X_{7}$ is the aspect related to habit. The model coefficients in Eq. (1) are determined by the least-squares method, and the significantly of each coefficient are checked statistically.

Table 1: The Eight Models Prior UTAUT and Their Variables

\begin{tabular}{|c|c|c|}
\hline Source & Theory & Variable(s) \\
\hline Rogers (1962) & IDT & $\begin{array}{l}\text { Relative Advantages, Compatibility, Complexity, Observability, } \\
\text { Image, Voluntariness of Use }\end{array}$ \\
\hline Fishbein \& Ajzen (1975) & TRA & Attitude, Subjective Norm \\
\hline Bandura (1977) & SCT & $\begin{array}{l}\text { Encouragement of Others, Use of Others, Support, Self-Efficacy, } \\
\text { Performance Outcome, Expectations, Personal Outcome, } \\
\text { Expectations, Affect }\end{array}$ \\
\hline Ajzen (1991) & TPB & Attitude, Subjective Norm, Perceived Behavioral, Control \\
\hline Thompson et al. (1991) & MPCU & $\begin{array}{l}\text { Social, Factors, Affect, Perceived Consequences, Facilitating } \\
\text { Conditions, Habits }\end{array}$ \\
\hline Davis et al. (1992) & MM & Motivation (Extrinsic and Intrinsic) \\
\hline Taylor \& Todd (1995) & TAM-TPB & $\begin{array}{l}\text { Perceived Usefulness, Perceived Ease of Use, Attitude, Subjective } \\
\text { Norm, Perceived Behavioral, Control }\end{array}$ \\
\hline $\begin{array}{l}\text { Venkatesh \& Davis } \\
\text { (2003) }\end{array}$ & TAM 2 & $\begin{array}{l}\text { Perceived Usefulness, Perceived Ease of Use, Subjective Norm, } \\
\text { Experience Voluntariness, Image, Job Relevance, Output Quality, } \\
\text { Result Demonstrability }\end{array}$ \\
\hline
\end{tabular}




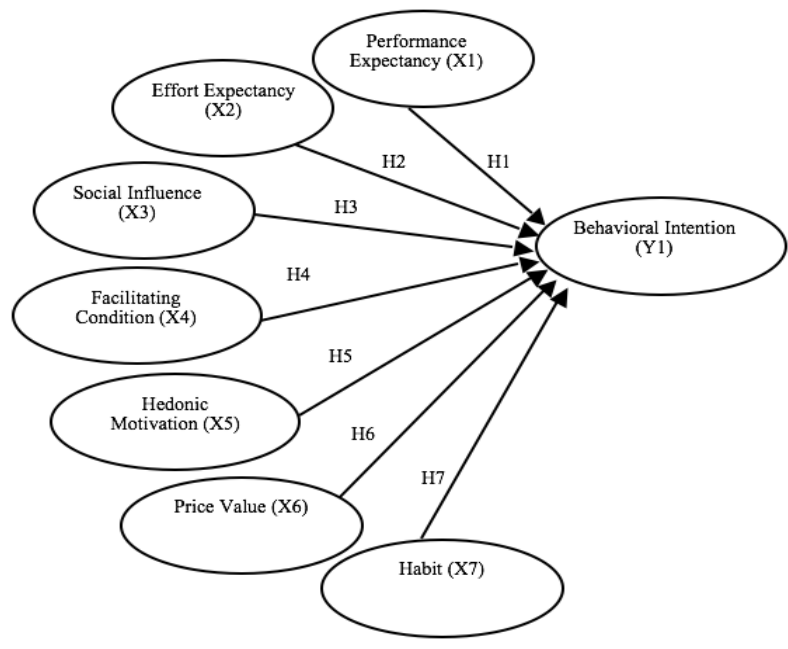

Figure 1 The Current Research Model.

\section{Results and Discussion}

The data collection instrument contains 23 questions. It is distributed to the users of digital membership apps. Most of the them are in lifestyle and automotive industries. From 345 respondents who received the questionnaires, only 301 returned the instrument fully filled.

The collected data are statistically analyzed by using SPSS software. To simplify the discussion, we abbreviate Performance Expectancy as PE, Effort Expectancy as EE, Facilitating Condition as FC, Social Influence as SI, Hedonic Motivation as HM, Price Value as PV, Habit as HT, and Behavioral Intention as BI. Table 2 shows the statistical description of the responses. From the descriptive statistic data in Table 2, the respondents seem to possess the tendency of positive attitude towards all variables in the study.

Table 2: The Statistical Description of the Respondent's Responses to Each Question.

\begin{tabular}{|c|c|c|c|c|}
\hline Variable & Question & Mean & SD & $\mathrm{M}(\mathrm{SD})$ \\
\hline \multirow{4}{*}{ PE } & PE1 & 3.60 & 1.073 & \multirow{4}{*}{$3.45(1.111)$} \\
\hline & PE2 & 3.52 & 1.107 & \\
\hline & PE3 & 3.48 & 1.178 & \\
\hline & PE4 & 3.23 & 1.088 & \\
\hline \multirow{4}{*}{$\mathrm{EE}$} & EE1 & 3.51 & 1.023 & \multirow{4}{*}{3.42 (1.071) } \\
\hline & EE2 & 3.48 & 1.062 & \\
\hline & EE3 & 3.38 & 1.101 & \\
\hline & EE4 & 3.31 & 1.100 & \\
\hline \multirow{2}{*}{ SI } & SI1 & 3.48 & 1.182 & \multirow{2}{*}{3.45 (1.129) } \\
\hline & SI2 & 3.42 & 1.076 & \\
\hline \multirow{3}{*}{ FC } & FC1 & 3.55 & 1.010 & \multirow{3}{*}{3.42 (1.074) } \\
\hline & FC2 & 3.53 & 1.110 & \\
\hline & FC3 & 3.20 & 1.104 & \\
\hline \multirow{2}{*}{ HM } & HM1 & 3.59 & 1.157 & \multirow{2}{*}{$3.56(1.142)$} \\
\hline & HM2 & 3.54 & 1.127 & \\
\hline \multirow{2}{*}{ PV } & PV1 & 3.46 & 1.163 & \multirow{2}{*}{3.39 (1.170) } \\
\hline & PV2 & 3.33 & 1.179 & \\
\hline \multirow{3}{*}{ HT } & HT1 & 3.67 & 1.088 & \multirow{3}{*}{3.6 (1.118) } \\
\hline & HT2 & 3.71 & 1.154 & \\
\hline & HT3 & 3.42 & 1.113 & \\
\hline \multirow{3}{*}{ BI } & BI1 & 3.38 & 1.016 & \multirow{3}{*}{3.25 (1.043) } \\
\hline & BI2 & 3.28 & 1.086 & \\
\hline & BI3 & 3.10 & 1.029 & \\
\hline
\end{tabular}

www.jbrmr.com A Journal of the Academy of Business and Retail Management (ABRM) 


\section{Reliability and Collinearity Tests}

The reliability of the responses is evaluated by using Cronbach's a, proposed by Cronbach (1951). The relation between the level of reliability and the a-value had been established by Cuieford (1965). A low a-value suggests a low reliability, and vice versa. A value of higher than 0.7 is considered to be highly reliable. His work is reproduced in Table 3.

The results of the reliability test are depicted in Table 4 . The values in the column Cronbach's Alpha Item Deleted are all higher than 0.7. These results conclude that the responses are rather reliable for all constructs.

In addition, the responses are also evaluated for potential collinearity by using Variance Inflation Factor (VIF) statistic. The results presented in Table 5 suggesting no collinearity existed in the responses.

Table 3: The Relation between the Reliability and the a-Value (CuieFord, 1965)

\begin{tabular}{|l|l|}
\hline Reliability & Range \\
\hline Unreliable & $a \leq 0.30$ \\
\hline Barely Reliable & $0.30<a \leq 0.40$ \\
\hline Slightly Reliable & $0.40<\alpha \leq 0.50$ \\
\hline Reliable & $0.50<a \leq 0.70$ \\
\hline Very Reliable & $0.70<a \leq 0.90$ \\
\hline Strongly Reliable & $a>0.70$ \\
\hline
\end{tabular}

Table 4: The Reliability of Responses for Each Construct.

\begin{tabular}{|c|c|c|}
\hline & Corrected Item Total Correlation & Cronbach's Alpha Item Deleted \\
\hline Performance Expectancy & .584 & .785 \\
\hline Effort Expectancy & .564 & .789 \\
\hline Social Influence & .567 & .785 \\
\hline Facilitating Conditions & .516 & .792 \\
\hline Hedonic Motivation & .450 & .814 \\
\hline Price Value & .577 & .783 \\
\hline Habit & .337 & .819 \\
\hline BI & .811 & .755 \\
\hline
\end{tabular}

Table 5: The Reliability of Responses for Each Construct.

\begin{tabular}{|c|c|c|}
\hline \multirow{2}{*}{ Indicator UTAUT } & \multicolumn{2}{|c|}{ Collinearity Statistic } \\
\cline { 2 - 3 } & Tolerance & VIF \\
\hline Performance Expectancy & .656 & 1.525 \\
\hline Effort Expectancy & .650 & 1.538 \\
\hline Social Influence & .670 & 1.492 \\
\hline Facilitating Conditions & .716 & 1.397 \\
\hline Hedonic Motivation & .726 & 1.378 \\
\hline Price Value & .651 & 1.536 \\
\hline Habit & .849 & 1.178 \\
\hline
\end{tabular}




\section{Results of Multiple Linear Regression Analysis}

Initially, we calculate the sum of different groups of questions (or scales) that belonged to different factors. As the answers to the survey are stored in the Excel document, corresponding columns of answers to the questions are integrated into one column that only presents one specific factor after the summing up. Subsequently, the new integrated column is regarded as an independent variable in regression testing in SPSS. Therefore, after regression test, researcher concluded the following results.

Firstly, we evaluate the model fitness by looking into the $R^{2}$-statistic. The results are: $R=0.822$, $R^{2}=0.675$, and adjusted $R^{2}=0.668$. These statistics are at standard error of the estimate of 0.407 . These results indicate that the model fits to the gathered data at a very high level of fitness.

The second statistical test applied to Model (1) is $F$-test, which evaluate the possibility of the values of the model coefficients take values significantly different than zero. The results of this statistical test are depicted in Table 6 showing that the $F$-value is very high of 100.30 with the associated $p$-value of 0.000 . These results advise that there are values of the model coefficients significantly deviate from zero.

The third statistical test is the $t$-test. The test is applied to the seven model coefficients, namely, $\beta_{1}, \beta_{2}, \cdots, \beta_{7}$. The results are presented in Table 7 . From these outputs, without any doubt, we conclude that the values of these coefficients are statistically significant.

\section{Implications of the Findings}

This section seeks to serve as best practice guide on how to build an effective mobile that strengthens the value of mobile loyalty app. As consumer expectation becomes higher when visiting sites on smartphone and tablet devices it's never been more important to build an effective mobile strategy. Price value needs to put their customers in control and think about how to effectively give the user a seamless mobile experience. Table 8 describe some points that have to notice when building new mobile loyalty app.

Table 6: The Results of the ANOVA Test.

\begin{tabular}{|c|c|l|l|l|c|}
\hline Model & Sum of Squares & df & Mean Square & F & Sig. \\
\hline Regression & 111.171 & 7 & 16.596 & 100.037 & 0.000 \\
\hline Residual & 55.907 & 337 & 0.166 & & \\
\hline Total & 172.078 & 344 & & & \\
\hline
\end{tabular}

Table 7: The Results of $t$-Test for Each Model Coefficients

\begin{tabular}{|c|l|l|l|l|l|}
\hline \multirow{2}{*}{ Model } & \multicolumn{2}{|c|}{ Unstandardized Coefficients } & $\begin{array}{c}\text { Standardized } \\
\text { Coefficients }\end{array}$ & $t$ & Sig. \\
\cline { 2 - 6 } & $B$ & Std. Error & Beta & & .000 \\
\hline (Constant) & -.606 & .156 & & -3.877 & .000 \\
\hline MEAN_PE & .195 & .039 & .194 & 5.070 & .000 \\
\hline MEAN_EE & .250 & .043 & .224 & 5.822 & .000 \\
\hline MEAN_SI & .173 & .035 & .190 & 5.012 & .001 \\
\hline MEAN_FC & .120 & .035 & .127 & 3.461 & .001 \\
\hline MEAN_HM & .076 & .022 & .124 & 3.441 & .000 \\
\hline MEAN_PV & .149 & .028 & .210 & 5.231 & .000 \\
\hline MEAN_HT & .149 & .027 & .187 & 5.556 & \\
\hline
\end{tabular}

Table 8: Implications of the Research for Best Practice to Build Mobile Loyalty App 


\begin{tabular}{|c|c|}
\hline Variable & Price Value \\
\hline $\mathrm{B}$ & 0.210 \\
\hline Description & $\begin{array}{l}\text { Making sure members are aware of the current promotions that enable them to } \\
\text { earn program points. } \\
\text { Create a sense of expectation on the customers to receive ads on weekly basis. } \\
\text { Build loyalty through recognition of customer's birthday. } \\
\text { Create a deeper relationship with rewarding members with special offers. } \\
\text { Personalization is paramount. Mobile devices are more personal than ever. For } \\
\text { the reason, your message should be more personal and relevant than ever } \\
\text { Ongoing relationship through SMS messages to remind customers about an } \\
\text { offer } \\
\text { SMS message sent reminding the customer about the offer and the offer's } \\
\text { expiration date } \\
\text { Coupon code used to track redemption } \\
\text { Use SMS to drive members to local stores }\end{array}$ \\
\hline Variable & Effort Expectancy \\
\hline B & 0.224 \\
\hline Description & $\begin{array}{l}\text { The look and feel of your mobile site: Minimize the number fields needed and } \\
\text { reduce any text entry through list options. } \\
\text { Make sure it's simple and easy to use for the sole purpose of improving the } \\
\text { brand experience and increasing customer loyalty } \\
\text { Choose the simplest input method for each task } \\
\text { Present an "Add to Passbook" application option so customers can store their } \\
\text { reward card on their mobile devices } \\
\text { Expand the ways to access and thus redeem rewards } \\
\text { Take advantage of mobile as an "on-the-go" coupon wallet }\end{array}$ \\
\hline
\end{tabular}

Table 8: Implications of ... (cont.)

\begin{tabular}{|c|l|}
\hline Variable & \multicolumn{1}{|c|}{ Performance Expectancy } \\
\hline B & 0.194 \\
\hline Description & $\begin{array}{l}\text { Search should be displayed prominently - clear navigation is a must to } \\
\text { ensure a simple user journey } \\
\text { Before developing an app, make sure there is a clear and defined use } \\
\text { case, understand what you want to get out of the app by setting KPIs } \\
\text { Focus on acquiring high-quality users, rather than just achieving an } \\
\text { initial high volume of downloads } \\
\text { Invest in app store optimization so that your app ranks highly in } \\
\text { search results and top chart rankings }\end{array}$ \\
\hline Variable & \multicolumn{1}{|c|}{ Social Influence } \\
\hline Bescription & $\begin{array}{l}\text { Consider the context of your audience for instance time of day and } \\
\text { connection type can give you a good indication of where, and what, } \\
\text { they are doing } \\
\text { Employ frequency capping to determine the optimum number of times } \\
\text { a consumer should be exposed to an ad to drive recall and make them } \\
\text { take action; this will help you reach as many engaged consumers as } \\
\text { possible } \\
\text { Increase exposure of the Rewards program to optimize its vility } \\
\text { and awareness } \\
\text { Facebook page sign-up for Rewards } \\
\text { Mobile Website enabling Rewards program sign-up } \\
\text { Test the impact of a stronger offer to re-engage inactive members }\end{array}$ \\
\hline
\end{tabular}




\begin{tabular}{|l|l|}
\hline & $\begin{array}{l}\text { Simple primary message presenting the bonus and the expiration of } \\
\text { the offer } \\
\text { Call to action: Shop online or find a store earned points }\end{array}$ \\
\hline Variable & \multicolumn{1}{|c|}{ Facilitating Condition } \\
\hline B & 0.127 \\
\hline Description & $\begin{array}{l}\text { Track your campaigns as much as possible, but be realistic; tracking } \\
\text { and attribution systems can't capture everything } \\
\text { Cookies don't work in the app environment. Make sure you track } \\
\text { Device ID's for remarketing purposes } \\
\text { A\&B test creative assets and post-click experiences as much as possible } \\
- \text { using analytical data will help you shape the user experience and } \\
\text { optimize its effectiveness }\end{array}$ \\
\hline
\end{tabular}

Table 8: Implications of ... (cont.)

\begin{tabular}{|l|l|}
\hline Variable & \multicolumn{1}{|c|}{ Hedonic Motivation } \\
\hline B & 0.124 \\
\hline Description & $\begin{array}{l}\text { Use a combination of in-app messaging and push notifications to reach your } \\
\text { entire audience with content and offers } \\
\text { Weekly email displaying featured products and their associated earned points } \\
\text { The same campaign is sent to members and non-members, so it is personalized } \\
\text { based upon the recipient's status }\end{array}$ \\
\hline Variable & Habit \\
\hline B & 0.187 \\
\hline Description & $\begin{array}{l}\text { Create a deeper relationship with rewarding members with special offers } \\
\text { Don't ignore user feedback and release regular updates to keep your content } \\
\text { fresh and give users a reason to come back }\end{array}$ \\
\hline
\end{tabular}

\section{Conclusion}

The following implications are recommended to business practitioners in the mobile industry to help them assess success factors for developing mobile apps. The effort expectancy and price value aspect should be taken seriously because these constructs are the most significant in the adoption intention of mobile apps. Besides creating apps that enhance enjoyment and excitement, business development should try to constantly reinforce users with value added services. Furthermore, app developers can alter users' habit that was cultivated elsewhere by providing greater benefits in their apps than their competitors. The construct EE is found to be more significant than PE in influencing the adoption intention. Therefore, system designers should emphasize the apps' functionality and usability from the customers' perspective apart from designing apps that are easy to access and navigate. Lastly, mobile marketing practitioners should focus on the real value of their apps by revising their marketing and pricing schemes to attract price-conscious consumers.

\section{References}

Ajzen, I. (1991). The theory of planned behavior. Organizational Behavior and Human Decision Processes, 50(2), 179211

Bandura, Albert (1977). Social Learning Theory, Englewood Cliffs, New Jersey, Prentice-Hall.

Bellman, S., Potter, R. F., Treleaven-Hassard, S., Robinson, J. A., \& Varan, D. (2011). The Effectiveness of Branded Mobile Phone Apps. Journal of Interactive Marketing, 25, 191-200.

Black K. Business statistics: for contemporary decision making. 6th ed. Hoboken: Wiley; 2010.

Booton, J. (2015, January 13). 5 predictions for mobile devices in 2015. Retrieved Jan 31st, 2017, from http://www.marketwatch.com/story/5-predictions-for-mobile-devices-in-2015-2015-01-13.

BuzzCity Report (2015), "The Quarterly Briefing on the Mobile Internet", vol.5, issue.2

Campbell, S.W. and Kwak, N. (2010) 'Mobile communication and civic life: linking patterns of use to civic and political engagement', Journal of Communication, Vol. 60, No. 3, pp.536-555.

Cronbach, L. J. (1951). Coefficient alpha and the internal structure of tests. Psychometrika, 16(3), 297-334.

Cuieford, J.P., Fundamental Statistics in Psychology and Education (4thed), McGraw-Hill, New York, NY (1965).

Davis, F. D., Bagozzi, R. P., \& Warshaw, P. R. (1992). Extrinsic and intrinsic motivation to use computers in the workplace. Journal of Applied Social Psychology, 22(14), 1111-1132.

www.jbrmr.com A Journal of the Academy of Business and Retail Management (ABRM) 
Fishbein, M. \& Ajzen, I. (1975). Belief, Attitude, Intention, and Behavior: An Introduction to Theory and Research. Reading, MA: Addison-Wesley.

Fujiwara, K. \& Nagasawa, S., Relationship between Purchase Intentions for Luxury Brands and Customer Experience-Comparative Verification Among Product Categories and Brand Ranks. Science Journal of Business and Management. Special Issue: Customer Experience Management/Marketing Branding. Vol. 3, No. 2-1, 2015, pp. 1-10. doi: 10.11648/j.sjbm.s.2015030201.11

Garson, G. D. (2012). Testing statistical assumptions (12th ed.). Asheboro: Statistical Associates Publishing.

Grapentine, T. (1997). Managing multicollinearity. Marketing Research, 9(3), 11- 21.

Hair, J. F., Babin, B., Money, A. H., \& Samouel, P. (2003). Essentials of Business Research Methods (1st ed.). New Jersey: John Wiley \& Sons, Inc.

Jayasingh, S., \& Eze, U. C. (2009). An empirical analysis of consumer behavioral intention toward mobile coupons in Malaysia. International Journal of Business and Information, 4(2), 221-242.

Kendal Peiguss (2012), “7 Customer Loyalty Programs That Actually Add Value”.

Kim, E., Lin, J.-S., \& Sung, Y. (2013). To App or Not to App: Engaging Consumers via Branded Mobile Apps. Journal of Interactive Advertising, 13(1), 53-65.

LaRue, E.M., Mitchell, A.M., Terhorst, L. and Karimi, H.A. (2010) 'Assessing mobile phone communication utility preferences in a social support network', Telematics \& Informatics, Vol. 27, No. 4, pp.363-369.

Magatef, S., \& Tomalieh, E. (2015). The Impact of Customer Loyalty Programs on Customer Retention. International Journal of Business and Social Science, Vol.6, No.8 (1),79.

Maghnati, F. \& Ling, K.C. (2013). Exploring the Relationship Between Experiential Value and Usage Attitude towards Mobile Apps Among the Smartphone Users. International Journal of Business and Management, 8(4), 1-9.

Ma, L. (2014), "Research and Development of Mobile Application for Android Platform", International Journal of Multimedia and Ubiquitous Engineering Vol.9, No.4.

Munnukka, J. (2004). Perception-based pricing strategies for mobile services in customer marketing context. University of Jyväskylä.

Rogers, Everett M. (1962), Diffusion of Innovations, New York, Free Press of Glencoe, RS(N)

Ronald L. Thompson, Christopher A. Higgins and Jane M. HowellSource: MIS Quarterly, Vol. 15, No. 1 (Mar. 1991), pp. 125-143

Singh Roopa \& Khan Imran (2012), "An Approach to Increase Customer Retention and Loyalty in B2C World", International Journal of Scientific and Research Publications, Volume2, Issue 6.

Taylor, S. and Todd, P. (1995), "Decomposition and crossover effects in the theory of planned behavior: a study of consumer adoption intentions", International Journal of Research in Marketing, Vol. 12, pp. 137-55

T. Casey and E. Wilson Evered, "Predicting up take of technology innovations in online family dispute resolution services: an application and extension of the UTAUT, "Computers in Human Behavior", vol.28, no.6, pp.20342045,2012.

T.L. Webb, P. Sheeran, and A. Luszczynska,"Planning to break unwanted habits: habit strength moderates implementation intention effects on behavior change, "British Journal of Social Psychology, vol.48, no.3, pp.507-523, 2009.

W. Reinartz, and V. Kumar (2004), "Getting the Most Out of All Your Customers," Harvard Business Review, 82 $(7 / 8), 116-23$.

Venkatesh, V., Morris, M. G., Davis, G. B., and Davis, F. D. 2003. “User Acceptance of Information Technology: Toward a Unified View," MIS Quarterly (27:3), 425-478.

Venkatesh, V., Thong, J. Y., \& Xu, X. (2012). Consumer acceptance and use of information technology: extending the unified theory of acceptance and use of technology. MIS quarterly, 36(1), 157-178. Wang, X., Chande, S., "An Investigation on the Characteristics of Mobile Applications: A Survey Study", International Journal of Information Technology and Computer Science (IJITCS), vol.6, no.11, pp.21-27, 2014. DOI: 10.5815/ijitcs.2014.11.03.

Venkatesh V., \& Davis F. (2000). A theoretical extension of the technology acceptance model: four longitudinal field studies. Management Science, 46(2), 186-204.

Vladar, A. and Fife, E. (2010). 'The growth of mobile social networking in the US: how far, how fast?', Intermedia, Vol. 38, No. 3, pp.30-33.

Wang, H. and Wang, S. (2010). 'User acceptance of mobile Internet based on the unified theory of acceptance and use of technology: investigating the determinants and gender differences', Social Behavior \& Personality: An International Journal, Vol. 38, No. 3, pp.415-426.

Yilmaz,Y.S., Aydin,B.,I. and Demirbas, M. (2014). “Google Cloud Messaging (GCM): An Evolution”, GC14SAC Internet of Things. New York. USA 